\title{
PENGEMBANGAN PENGELOLAAN WAKAF DI ERA KONTEMPORER
}

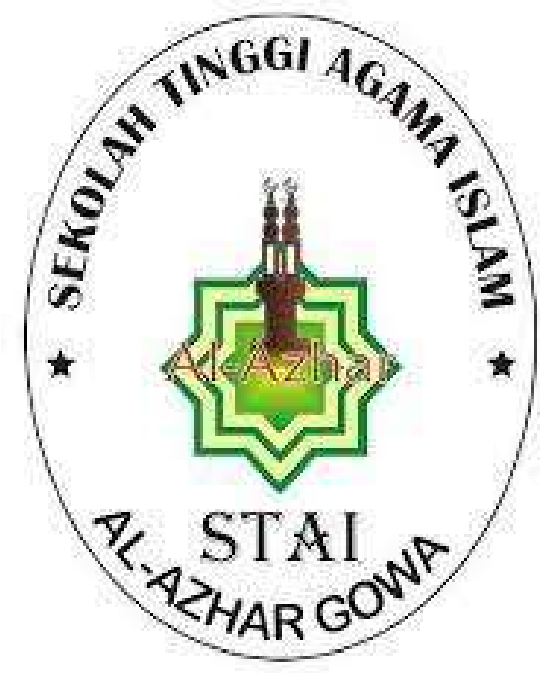

Makalah Diajukan untuk memenuhi tugas mata kuliah fikih zakat dan wakaf

Oleh :

Enny Winarni

Nafisah Kuri'ain

Dosen :

Samsul Arifai, S.A.B., M.A.

\section{EKONOMI SYARIAH}

STAI AL-AZHAR GOWA

2021 


\section{KATA PENGANTAR}

Puji syukur diucapkan kehadirat Allah SWT atas segala rahmatNya sehingga makalah ini dapat tersusun sampai dengan selesai. Tidak lupa kami mengucapkan terimakasih terhadap bantuan dari pihak yang telah berkontribusi dengan memberikan sumbangan baik pikiran maupun materinya.

Penulis sangat berharap semoga makalah ini dapat menambah pengetahuan dan pengalaman bagi pembaca. Bahkan kami berharap lebih jauh lagi agar makalah ini bisa pembaca praktekkan dalam kehidupan sehari-hari.

Bagi kami sebagai penyusun merasa bahwa masih banyak kekurangan dalam penyusunan

makalah ini karena keterbatasan pengetahuan dan pengalaman Kami. Untuk itu kami sangat mengharapkan kritik dan saran yang membangun dari pembaca demi kesempurnaan makalah ini.

Makassar, 1 Januari 2022 


\section{DAFTAR ISI}

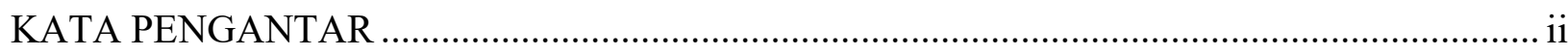

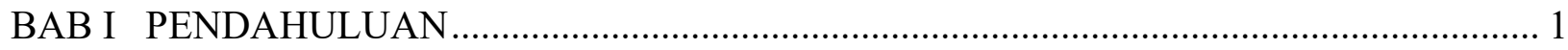

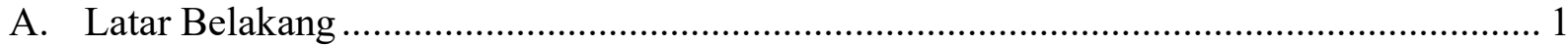

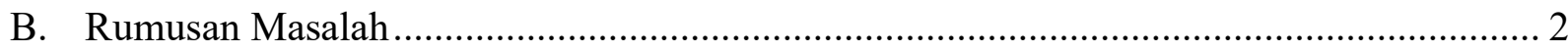

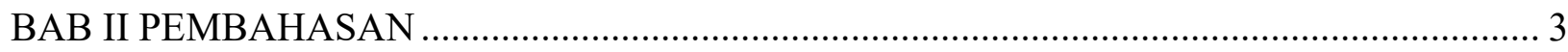

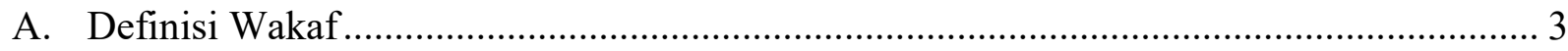

B. Pengelolaan Wakaf Di Era Kontemporer ................................................................... 3

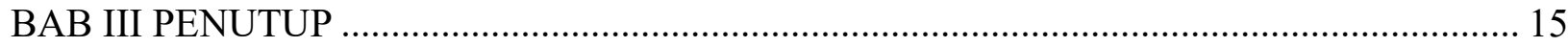

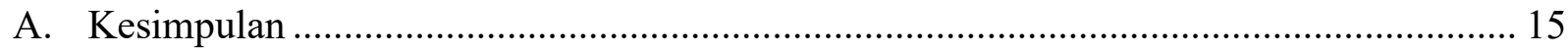

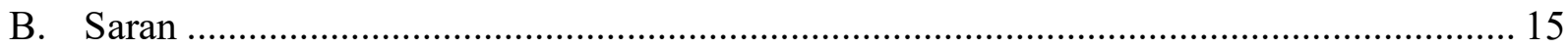

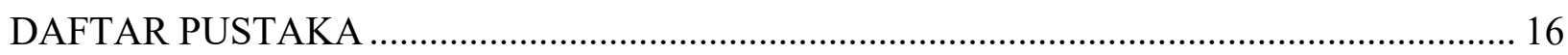




\section{BAB I \\ PENDAHULUAN}

\section{A. Latar Belakang}

Perwakafan atau wakaf merupakan pranata dalam keagamaan Islam yang sudah mapan. Dalam hukum Islam, wakaf tersebut termasuk kedalam kategori ibadah kemasyarakatan (ibadah ijtima'iyyah). Oleh karena itu Islam meletakkan amalan wakaf sebagai salah satu macam ibadah yang amat digembirakan. Masyarakat Arab sebelum Islam telah mempraktekkan sejenis wakaf, sebab pada masa itu telah dikenal praktek sosial yang diantaranya adalah menderma sesuatu dari seseorang kepentingan umum atau dari satu orang untuk keluarga. Sejak datangnya agama Islam di Indonesia pada abad ke-7 Masehi, perwakafan tanah telah ada dan berlaku dalam masyarakat Indonesia berdasarkan hukum Islam dan hukum adat, meski belum ada peraturan perundangan tertulis yang mengaturnya. Adapun benda yang diwakafkan pada waktu itu pada umumnya adalah benda-benda tak bergerak (seperti tanah) dan eksistensi wujudnya akan terus ada hingga akhir zaman. Biasanya wakaf ini berupa properti seperti, Masjid, tanah, bangunan sekolah, pondok pesantren, dan lain-lain. Sementara, kebutuhan masyarakat saat ini sangat besar sehingga mereka membutuhkan dana tunai untuk meningkatkan kesejahteraan. Wakaf dikenal sebagai aset umat yang pemanfaatan dapat dilakukan sepanjang masa. Namun, pengelolaan dan pendayagunaan harta wakaf secara produktif di Indonesia masih ketinggalan dibandingkan dengan negara Islam lainnya. Hasil penelitian wakaf menunjukkan bahwa beberapa negara pada mulanya wakaf kurang berfungsi bagi perekonomian umat. Keadaan ini pada umumnya disebabkan wakaf tidak dikelola dengan manajemen yang baik. Barulah kemudian, dengan regulasi yang diatur pemerintah dalam Undang-Undang tentang wakaf, wakaf mulai dikelola dengan manajemen yang baik. 


\section{B. Rumusan Masalah}

1. Apa definisi wakaf?

2. Bagaimana pengelolaan wakaf di era kontemporer? 


\section{BAB II \\ PEMBAHASAN}

\section{A. Definisi Wakaf}

Wakaf adalah perbuatan hukum seseorang atau kelompok orang atau badan hukum yang memisahkan sebagian dari benda miliknya dan melembagakannya untuk selamalamanya guna kepnetingan ibadah atau keperluan umum lainnya sesuai dengan ajaran Islam.

Wakaf adalah perbuatan hukum wakif untuk memisahkan dan/atau menyerahkan sebagian harta benda miliknya untuk dimanfaatkan selamanya atau untuk jangka waktu tertentu sesuai dengan kepentingannya guna keperluan ibadah dan/atau kesejahteraan umum menurut syariah. ${ }^{1}$

Dari definisi wakaf tersebut, dapat disimpulkan bahwa wakaf bertujuan untuk memberikan manfaat atau faedah harta yang diwakafkan kepada orang yang berhak dan dipergunakan sesuai dengan ajaran syariah Islam. Hal ini sesuai dengan fungsi wakaf yang disebutkan pasal 5 UU no. 41 tahun 2004 yang menyatakan wakaf berfungsi untuk mewujudkan potensi dan manfaat ekonomis harta benda wakaf untuk kepentingan ibadah dan untuk memajukan kesejahteraan umum. ${ }^{2}$

\section{B. Pengelolaan Wakaf Di Era Kontemporer}

Saat ini ada beberapa negara yang pengelolaan dan manajemen wakafnya sangat memprihatinkan. Sebagai akibatnya cukup banyak harta wakaf terlantar dalam pengelolaannya, bahkan ada harta wakaf yang hilang. Salah satu sebabnya antara lain adalah karena umat Islam (wakif) pada umumnya hanya mewakafkan tanah dan

\footnotetext{
${ }^{1}$ Fawza Rahmat, "Pengelolaan Wakaf Kontemporer," Journal of Chemical Information and Modeling 53, no. 9 (2013): 1689-99.

${ }^{2}$ Badan Wakaf Indonesia, "Pengertian Wakaf," n.d., https://bwikotamalang.com/pengertian-wakaf.
} 
bangunan sekolah saja, kurang memikirkan biaya operasional sekolah, dan nazhirnya juga kurang profesional.

Oleh karena itu kajian mengenai manajemen pengelolaan wakaf ini sangat penting. Kurang berperannya wakaf dalam memberdayakan ekonomi umat di Indonesia dikarenakan wakaf tidak dikelola secara produktif. Untuk mengatasi masalah ini, paradigma baru dalam pengelolaan wakaf harus diterapkan. Wakaf harus dikelola secara produktif dengan menggunakan manajemen modern. Untuk mengelola wakaf secara produktif, ada beberapa hal yang perlu dilakukan sebelumnya. Selain perumusan konsepsi fikih wakaf dan peraturan perundangundangan, nazhir juga harus dibina menjadi nazhir profesional untuk mengembangkan harta yang dikelolanya, apalagi jika harta wakaf tersebut berupa uang. Di samping itu, untuk mengembangkan wakaf secara nasional, diperlukan badan khusus yang antara melakukan pembinaan nazhir. Badan wakaf dimaksud sudah ada di beberapa negara, antara Badan Wakaf Mesir, Badan Wakaf Sudan, dan lain-lain. Di Indonesia diharapkan dalam waktu dekat juga dibentuk Badan Wakaf Indonesia.

Pada saat ini, di Indonesia sedang dilakukan sosialisasi wakaf uang. Di negara lain seperti Turki, Kuwait, Bangladesh sudah cukup lama dikembangkan, sehingga dapat mengembangkan harta benda wakaf yang lain. Hasil pengelolaan wakaf di negara-negara tersebut sangat membantu menyelesaikan berbagai masalah umat, khususnya masalah sosial dan ekonomi masyarakat.

1. Wakaf Tunai/Uang

Wakaf tunai adalah wakaf yang dilakukan seseorang, kelompok orang, dan lembaga atau badan hukum dalam bentuk uang tunai. ${ }^{3}$ Terdapat perbedaan pendapat mengenai hukum wakaf tunai. Imam Al-Bukhari mengungkapkan bahwa imam Az-Zuhri berpendapat dinar dan dirham boleh diwakafkan. Caranya ialah dengan menjadikan dinar dan dirham itu sebagai modal usaha

\footnotetext{
${ }^{3}$ ACTNews, “Wakaf Tunai," 12 February 2017, n.d., https://news.act.id/berita/wakaf-tunai.
} 
(dagang), kemudian menyalurkan keuntungannya sebagai wakaf. Wahbah AzZuhaili juga mengungkapkan bahwa mazhab Hanafi membolehkan wakaf tunai sebagai pengecualian atas dasar istihsan bi al-'urf karena sudah banyak dilakukan masyarakat. Mazhab Hanafi memang berpendapat bahwa hukum yang ditetapkan berdasarkan 'urf (adat) mempunyai kekuatan yang sama dengan hukum yang ditetapkan berdasarkan nash (teks). Melihat perkembangan zaman, dan sesuatu hal yang tidak dapat disanggah bahwa uang merupakan suatu variabel penting dalam pembangunan ekonomi masyarakat, dan akhirnya MUI mengeluarkan fatwa berkenaan diperbolehkannya wakaf uang dengan dasar pertimbangan antara lain: ${ }^{4}$

a. Firman Allah SWT

Surat al-Baqarah ayat 261-262:

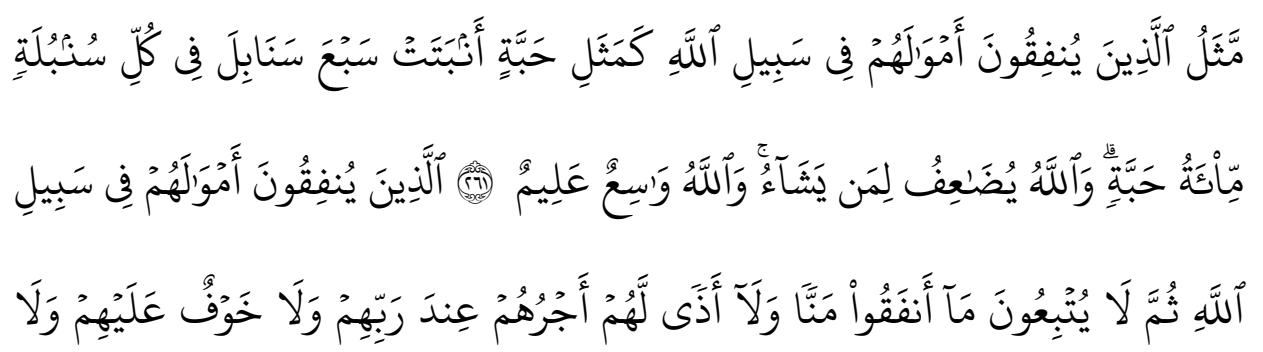

هُمْن يَحَزَنْونَن

Artinya: 261. Perumpamaan (nafkah yang dikeluarkan oleh) orangorang yang menafkahkan hartanya di jalan Allah adalah serupa dengan sebutir benih yang menumbuhkan tujuh bulir, pada tiap-tiap bulir seratus biji. Allah melipat gandakan (ganjaran) bagi siapa yang dia kehendaki. dan Allah Maha luas (karunia-Nya) lagi Maha Mengetahui. 262. Orang-orang yang menafkahkan hartanya di jalan Allah, Kemudian mereka tidak mengiringi apa yang dinafkahkannya itu dengan menyebut-

\footnotetext{
${ }^{4}$ Rahmat, "Pengelolaan Wakaf Kontemporer."
} 
nyebut pemberiannya dan dengan tidak menyakiti (perasaan si penerima), mereka memperoleh pahala di sisi Tuhan mereka. tidak ada kekhawatiran terhadap mereka dan tidak (pula) mereka bersedih hati.

b. Hadis Nabi ${ }^{5}$

- Diriwayatkan dari Abu Hurairah ra bahwa Rasulullah bersabda: apabila manusia meninggal dunia terputuslah (pahala) amal perbuatannya kecuali tiga hal, yaitu shadaqah jariyah (wakaf), ilmu yang bermanfaat, anak yang shaleh yang mendo'akannya. (H.R. Muslim al-Thirmidzi, alNasa'i, dan Abu Daud)

- Diriwayatkan dari Ibnu Umar ra, bahwa Umar bin Khatab ra memperoleh tanah di Khaibar, lalu ia datang kepada Nabi untuk minta petunjuk mengenai tanah tersebut, ia berkata: wahai Rasulullah, saya memperoleh tanah di Khaibar, yang belum pernah saya peroleh harta yang lebih baik bagiku melebihi tanah tersebut, apa perintah engkau mengenainya? Nabi menjawab, jika mau, kamu tahan pokoknya dan kamu sedekahkan hasilnya. Ibnu Umar berkata, maka Ibnu Umar menyedekahkan tanah tersebut dengan syarat tanah itu tidak dijual, tidak dihibahkan, dan tidak diwariskan. Ia menyedekahkan kepada fuqara, kerabat, riqab (hamba sahaya dan orang tertindas), sabilillah, ibnu sabil, dan tamu. Tidak berdosa dari orang yang mengelola untuk memakan dari tanah itu secara ma'ruf (wajar) dan memberi makan kepada orang lain tanpa menjadikannya sebagai harta hak milik. (H.R. Bukhari, Muslim, al-Thirmidzi dan nasa'i)

Ulama yang membolehkan wakaf uang berpendapat, bahwa uang dapat diwakafkan asalkan uang tersebut diinvestasikan dalam usaha bagi hasil (mudlarabah), kemudian keuntungannya disalurkan sesuai dengan tujuan wakaf. Dengan demikian uang yang diwakafkan tetap, sedangkan yang disampaikan

${ }^{5}$ Rahmat. 
kepada mauquf 'alaih adalah hasil pengembangan wakaf uang itu. Pada saat ini sudah cukup banyak bermunculan bentuk baru pengelolaan wakaf uang. Munculnya bentuk-bentuk pengelolaan wakaf uang tersebut tidak terlepas dari munculnya berbagai bentuk investasi dan berbagai cara dalam pengelolaan ekonomi. Salah satu bentuk baru dalam pengelolaan wakaf uang adalah wakaf uang yang dikelola oleh perusahaan investasi. Biasanya wakaf uang di sini dikelola atas asas mudlarabah. Dalam hal ini uang diserahkan kepada badan atau yayasan yang menerima pinjaman usaha bagi hasil atau kepada yayasan yang dikelola oleh pengelola sewaan, sedangkan hasilnya diberikan kepada mauquf 'alaih sebagai amal kebaikan sesuai dengan tujuan wakaf.

Perdebatan tentang hukum wakaf uang telah selesai dengan dibolehkannya wakaf uang dalam fatwa MUI tahun 2002 dan diatur pelaksanaannya dalam peraturan perundang-undangan tentang wakaf. Hanya saja masih ada persoalanpersoalan teknis tentang wakaf uang terutama persoalan menurunnya nilai mata uang akibat inflasi dan jaminan wakaf uang yang dimanfaatkan untuk kegiatan investasi. Terhadap persoalan tersebut, ada beberapa solusi untuk mengatasinya sebagaimana diungkapkan oleh Al-Aiyashi Al-Sadiq Faddad dalam tulisannya yang berjudul Aplikasi Wakaf Uang: Pertanyaan dan Persoalan Syariah, yaitu:

1. Adanya penjaminan atas investasi wakaf uang atau investasi wakaf uang dijamin oleh asuransi syariah.

2. Jaminan bersama antara kelompok usaha yang dibiayai dari dana wakaf uang dalam bentuk tolong menolong, yaitu apabila salah satu dari mereka gagal bayar atau tidak mampu membayar cicilan, maka dibayar oleh yang lain.

3. Pembiayaan dengan uang wakaf dinilai dengan emas atau dengan mata uang yang stabil nilainya yaitu dengan nilai yang berlaku pada saat akad 
4. Membuat dana khusus atau cadangan untuk investasi yang gagal atau rugi yang bersumber dari uang wakaf dan untuk menutupi penurunan nilai uang atau inflasi.

5. Mengalokasikan sejumlah dana yang diambil dari hasil pengelolaan wakaf untuk memperkuat pokok wakaf khususnya apabila telah disebutkan dalam dokumen wakaf dan dianggap sebagai syarat yang disetujui oleh wakif. Keputusan Muktamar Fikih di Kuwait yang ke-4 tentang Lembaga Keuangan Islam menyatakan bahwa tidak disyaratkan dalam pengalokasian hasil wakaf adanya syarat wakif karena hal itu sebagai ketentuan investasi dan diatur dalam standar akuntansinya.

6. Menggunakan kelebihan hasil wakaf (jika ada) untuk menjaga dan mengembangkan pokok harta wakaf. Nazhir harus membagikan hasil wakaf kepada penerima manfaat wakaf, namun jika masih ada kelebihannya maka boleh diinvestasikan untuk pengembangan wakaf.

7. Meminjam uang dengan skema qhardul hasan atau dengan skema lain yang sesuai syariah untuk menutupi kerugian investasi wakaf dan menjaga pokok wakaf yang pembayarannya bersumber dari hasil investasi wakaf $^{6}$

Badan Wakaf Indonesia (BWI) yang diberi kewenangan segai nazhir untuk mengelola dan mengembangkan harta benda wakaf berskala nasional dan internasional, berupaya membuat program wakaf uang dengan investasinya yang aman (secure), menguntungkan (profitable), dan sesuai dengan syariah serta peraturan perundang-undangan. BWI bekerja sama dengan Kementerian Agama, Kementerian Keuangan, Bank Indonesia, Forum Wakaf Produktif, Bank Muamalat, BNI Syariah sebagai bank operasional (masih terbuka bank syariah lainnya khususnya yang telah menjadi LKS-PWU menjadi bank operasional) membuat proram wakaf uang yang diberi nama Cash Waqf Linked Sukuk (Wakaf Uang Link

6 "Wakaf Kontemporer ii," n.d. 
Sukuk). Wakaf uang link sukuk ini diluncurkan pada Pertemuan Tahunan Dana Moneter Internasional - Bank Dunia (IMF-World Bank) di Nusa Dua Bali tanggal 12-14 Oktober 2018. Selanjutnya pada tanggal 1 November 2018 dilakukan penanda-tanganan Nota Kesepahaman antara BWI, Kementerian Agama, Kementerian Keuangan, dan Bank Indonesia tentang Pengembangan Cash Waqf Linked Sukuk (CWLS). Wakaf uang link sukuk adalah wakaf uang yang ditempatkan pada Sukuk Negara untuk pengelolaan wakaf secara produktif yang aman karena dijamin negara, produktif karena ada imbal hasil dari sukuknya, optimal karena imbal hasil sukuknya kompetitif dan tidak dipotong pajak, dan barokah karena imbal hasilnya mengalir untuk masyarakat kurang mampu.

Wakaf uang link sukuk ini terbuka untuk wakaf uang selamanya dan wakaf uang untuk jangka waktu tertentu. Bagi yang memilih wakaf uang untuk jangka waktu tertentu yaitu lima tahun, maka pada tahun kelima dana wakafnya kembali. Bagi yang berwakaf selamanya maka setelah periode sukuknya berakhir, akan ditempatkan lagi di sukuk seri berikutnya atau diinvestasikan pada produk lembaga keuangan syariah atau instrumen keuangan syariah lainnya atau diinvestasikan secara langsung.

Untuk lebih jelasnya, berikut ini penjelasan skema wakaf uang link sukuk: 1. Wakif mewakafkan uang miliknya melalui mitra nazhir atau LKS-PWU kepada nazhir BWI dengan dua pilihan: (1) Wakaf uang untuk jangka waktu tertentu minimal 5 juta untuk jangka waktu minimal 5 tahun. (2) Wakaf Uang Selamanya. 2. Wakif menyetorkan dana wakaf uang ke rekening mitra nazhir di LKS-PWU dan setelahnya melakukan Ikrar Wakaf dihadapan pejabat bank yang ditunjuk sebagai Pejabat Pembuat Akta Ikrar Wakaf (PPAIW) yang dituangkan dalam Akta Ikrar Wakaf. Dalam hal wakif tidak dapat hadir di hadapan PPAIW, maka wakif dapat menunjuk wakil atau kuasanya .

3. Setoran dana wakaf uang dari wakif ditempatkan di rekening wadiah atas nama mitra nazhir sebelum ditempatkan ke rekening nazhir BWI. 
4. Oleh BWI apabila jumlah kumulatif dari seluruh mitra nazhir telah mencapai 50 Milyar, BWI memindahkan dana wakaf uang yang ada di rekening mitra nazhir ke rekening BWI di LKS PWU sebagai wadiah.

5. Dana wakaf uang yang sudah terhimpun 50 milyar yang ada direkening BWI dibelikan SBSN yang diterbitkan oleh Kementerian Keuangan untuk jangka waktu tertentu.

6. Dana wakaf uang yang sudah dibelikan Surat Berharga Syariah Negara (SBSN) atau Sukuk Negara, oleh Kementerian Keuangan dimanfaatkan untuk pembiayaan proyek pemerintah di bidang layanan umum masyarakat.

7. Kementerian Keuangan membayarkan kupon SBSN atau Sukuk Negara kepada nazhir BWI sesuai dengan kontrak.

8. Oleh Nazhir BWI kupon SBSN atau Sukuk Negara setelah dikurangi hak nazhir sebanyak $10 \%$ dan biaya pengelolaannya, disalurkan melalui mitra nazhir untuk membiayai pembangunan aset wakaf atau fasilitas umum seperti madrasah, rumah sakit, dan lain-lain. Untuk tahap awal kupon keuntungannya untuk layanan gratis bagi dhuafa yang menderita penyakit katarak di Rumah Sakit Mata Achmad Wardi BWI-Dompet Dhuafa di Kota Serang Banten.

9. Kementerian Keuangan mengembalikan dana wakaf uang kepada BWI setelah SBSN atau Sukuk Negara jatuh tempo.

10. BWI memerintahkan kepada mitra nazhir dan LKS-PWU untuk mengembalikan dana wakaf uang untuk jangka waktu tertentu kepada wakif.

11. Pengembalian dana wakaf uang kepada wakif melalui bank operasional yang telah ditunjuk BWI.

12. Kementerian Agama dan Badan Wakaf Indonesia melakukan pengawasan program wakaf uang link sukuk. ${ }^{7}$

2. Wakaf saham

7 "Wakaf Kontemporer ii." 
Saham sebagai barang yang bergerak juga dipandang mampu menstimulus hasil-hasil yang dapat didedikasikan untuk umat, Bahkan dengan modal yang besar, Saham malah justru akan memberi kontribusi yang cukup besar dibandingkan jenis perdagangan yang lain. Termasuk juga bagian yang disebut dalam wakaf produktif adalah wakaf saham. Saham sebagai barang yang bergerak juga dipandang mampu menstimulus hasilhasil yang dapat di dedikasikan untuk kepentingan umat kebanyakan. Bahkan, dengan modal yang besar, saham malah justru akan memberi konstribusi yang cukup besar di banding jenis komoditas perdagangan yang lain.

Dalam sebuah perusahaan, seorang penguasa dapat mengkhususkan peruntukan sebagian sahamnya sebagai harta wakaf yang hasilnya (deviden) untuk tanya-tanya digunakan untuk kemaslahatan umat. Wakaf saham boleh juga diambil dari keuntungan seluruh saham yang dimiliki pemiliknya. Semua itu tergantung pada keinginan dan kehendak pemilik saham. Sebab, yang penting bukanlah nominal besar-kecilnya hasil saham, melainkan lebih pada komitmen keberpihakan para wakif terhadap kesejahteraan umat Islam. Wakaf saham, hanya hendak mewakafkan sebagian hasil saham yang dimiliki wakif kepada umat. Pangsa pasar yang dibidik oleh wakaf saham dengan begitu hanya terbatas para pemegang saham yang kebanyakan kelas menengah ke atas. Demikian ini sangat tepat, mengingat kebanyakan umat Islam, terutama mereka yang secara ekonomi telah mapan, terpaksa dibuat bingung untuk mendayagunakan hartanya di jalan Allah SWT. Dengan adanya wakaf saham, maka sedikit banyak harta mereka dapat digunakan untuk kesejahteraan ekonomi umat yang ada di bawah garis kemiskinan. ${ }^{8}$

\footnotetext{
${ }^{8}$ Veithzal Rizal ainal, "PENGELOLAAN DAN PENGEMBANGAN WAKAF PRODUKTIF Oleh : Veithzal Rivai Zainal Anggota Dewan Pertimbangan Badan Wakaf Indonesia (BWI)," Ziswaf 9 (2016): 1-16.
} 
Menurut Dr. Oni Sahroni (Anggota Dewan Syariah Nasional Majelis Ulama Indonesia) dalam tulisannya pada Republika.co.id (Sahroni, 2018) menerangkan wakaf saham dalam tinjauan fiqih; wakaf saham itu dibolehkan dalam Islam dengan syarat saham yang diwakafkan itu saham syariah (yang memiliki underlying asset yang halal) sesuai peraturan perundang-undangan, dilakukan istibdal, dan saham yang diwakafkan itu jelas objek dan nilainya. Kesimpulan hukum ini berdasarkan telaah terhadap keputusan Standar Syariah Internasional AAOIFI tentang wakaf saham, regulasi, dan peraturan perundang-undangan tentang wakaf, Fatwa Dewan Syariah nasional MUI tentang saham, dan literatur fikih turats tentang wakaf.

1. Saham yang diwakafkan adalah saham syariah. Saham sebagaimana tersebut itu halal sesuai Fatwa DSN MUI No 40/DSN-MUI/X/2002 tentang Pasar Modal dan Pedoman Umum Penerapan Prinsip Syariah di Bidang Pasar Modal dan Standar Syariah Internasional. Hal yang sama ditegaskan oleh regulasi bahwa saham tidak bertentangan dengan prinsip syariah karena saham merupakan surat berharga bukti penyertaan modal dari investor kepada perusahaan yang kemudian investor akan mendapatkan bagi hasil berupa dividen (Hana, 2018). Konsep penyertaan modal dengan hak bagi hasil usaha ini merupakan konsep yang tidak bertentangan dengan prinsip syariah atau kegiatan musyarakah/syirkah. Jika underlying asset saham tersebut itu halal, mewakafkan saham tersebut itu berarti mewakafkan aset yang halal layaknya mewakafkan aset-aset yang bergerak atau tidak bergerak yang halal dan murah.

2. Saham yang diwakafkan itu jelas objek dan nilainya. Misalnya, mewakafkan berapa lembar saham, nilainya, dan termasuk apakah yang diwakafkan itu sahamnya atau hanya manfaat (benefit) sahamnya, masingmasing memiliki konsekuensi hukumnya. 
3. Sejak diwakafkan, saham tersebut itu dimiliki oleh mustahik yang dikuasakan kepada nazir untuk dikelola, sehingga menghasilkan manfaat yang diperuntukkan bagi mustahik.

4. Istibdal terhadap saham jika sudah selesai masa investasinya. Maksudnya adalah mengubah aset wakaf dengan cara dijual atau ditukar dengan aset lain sebagai pengganti karena ada maslahat wakaf. ${ }^{9}$

Wakaf saham tersebut dibolehkan menurut Standar Syariah Internasional AAOIFI yang menegaskan, wakaf saham dan sukuk investasi diperbolehkan dengan catatan pada saat tashfiyah, dilakukan istibdal. Selanjutnya, manfat wakaf (hasil investasi saham) disalurkan kepada penerima manfaat wakaf. Menurut Standar Syariah AAOIFI, landasan bolehnya wakaf saham merujuk pada bolehnya wakaf uang. Standar tersebut menyebutkan, landasan bolehnya wakaf uang adalah karena wakaf uang itu sebagai induk hukum (ashl). Pendapat ini adalah pendapat Muhammad bin Abdullah Al-Anshari, sahabat Imam Zufar yang dipilih oleh Imam ibn Taimiyah. Kesimpulan yang sama terjadi pada wakaf saham dan sukuk.

Saham merupakan jenis benda bergerak yang dapat diwakafkan menurut UU Wakaf. Penelitian ini membahas wakaf dalam mewujudkan keadilan distribusi ekonomi, pengaturan saham syariah sebagai objek wakaf,dan upaya perlindungan hukum saham syariah sebagai objek wakaf. Metode yang digunakan dalam penelitian ini adalah metode penelitian hukum normatif (legal research) yang dilakukan dengan pendekatan perundang-undangan dan pendekatan konsep keadilan menurut hukum Islam. Berdasarkan hasil penelitian, secara teoritik tujuan wakaf adalah untuk merealisir keadilan sosial (adminekonomisyariah.org, 2017).

\footnotetext{
${ }^{9}$ Muzayyanah Dini Selasi, "Wakaf Saham Sebagai Alternatif Wakaf Produktif Pada Perkembangan Ekonomi Syariah di Indonesia," Tawazun: Journal of Sharia Economic Law, 2020, file:///C:/Users/ASUS/Documents/kombeo/793227516-2-PB.pdf.
} 
Wakaf Saham dan Surat Berharga dapat Anda serahkan kepada Tabung Wakaf Indonesia sebagai niat baik Anda memperoleh amal jariyah. Surat-surat berharga yang dapat Anda wakafkan antara lain (dompet dhuafa, 2017):

- Saham Perusahaan Syariah Terbuka (Terdaftar di Bursa Efek)

- Goodwill Saham Perusahaan Syariah Tertutup

- Sukuk (Obligasi) Syariah

- Sukuk (Obligasi) Retail Syariah

- Deposito Syariah

- Reksadana Syariah

- Wasiat Wakaf dalam Polis Asuransi ${ }^{10}$

${ }^{10}$ Dini Selasi. 


\section{BAB III}

\section{PENUTUP}

\section{A. Kesimpulan}

Wakaf adalah perbuatan hukum seseorang atau kelompok orang atau badan hukum yang memisahkan sebagian dari benda miliknya dan melembagakannya untuk selama-lamanya guna kepnetingan ibadah atau keperluan umum lainnya sesuai dengan ajaran Islam. Pada saat ini, di Indonesia sedang dilakukan sosialisasi wakaf uang. Di negara lain seperti Turki, Kuwait, Bangladesh sudah cukup lama dikembangkan, sehingga dapat mengembangkan harta benda wakaf yang lain. Hasil pengelolaan wakaf di negara-negara tersebut sangat membantu menyelesaikan berbagai masalah umat, khususnya masalah sosial dan ekonomi masyarakat.

- Wakaf Tunai/Uang, adalah wakaf yang dilakukan seseorang, kelompok orang, dan lembaga atau badan hukum dalam bentuk uang tunai

- Wakaf Saham, Saham sebagai barang yang bergerak juga dipandang mampu menstimulus hasil-hasil yang dapat didedikasikan untuk umat, Bahkan dengan modal yang besar, Saham malah justru akan memberi kontribusi yang cukup besar dibandingkan jenis perdagangan yang lain.

\section{B. Saran}

Untuk mengembangkan wakaf di suatu negara, di samping syarat-syarat yang sudah penulis kemukakan, ada hal yang sangat penting untuk ditekankan yaitu komitmen bersama antara pemerintah, umat Islam dan para nazhir wakaf. Di samping itu, di masa yang akan datang diperlukan kerjasama antar Badan Wakaf yang ada di seluruh dunia Islam termasuk Badan Wakaf Indonesia yang insya Allah sebentar lagi terwujud. Dengan demikian berbagai permasalahan umat Islam khususnya masalah sosial dan ekonomi dapat diselesaikan bersamasama. Wallahu a'lam. Semoga Allah memudahkan semuanya. 


\section{DAFTAR PUSTAKA}

ACTNews. "Wakaf Tunai." 12 February 2017, n.d. https://news.act.id/berita/wakaf-tunai.

Dini Selasi, Muzayyanah. "Wakaf Saham Sebagai Alternatif Wakaf Produktif Pada

Perkembangan Ekonomi Syariah di Indonesia." Tawazun: Journal of Sharia Economic Law, 2020. file://C:/Users/ASUS/Documents/kombeo/7932-27516-2-PB.pdf.

Indonesia, Badan Wakaf. "Pengertian Wakaf," n.d. https://bwikotamalang.com/pengertian-wakaf.

Rahmat, Fawza. "Pengelolaan Wakaf Kontemporer." Journal of Chemical Information and Modeling 53, no. 9 (2013): 1689-99.

Veithzal Rizal ainal. "PENGELOLAAN DAN PENGEMBANGAN WAKAF PRODUKTIF

Oleh : Veithzal Rivai Zainal Anggota Dewan Pertimbangan Badan Wakaf Indonesia (BWI)." Ziswaf 9 (2016): 1-16.

"Wakaf Kontemporer ii," n.d. 